\title{
MERUNTUHKAN STATUS QUO: PARTISIPASI POLITIK DAN KEKERASAN DALAM GERAKAN MAHASISWA DI INDONESIA (TINJAUAN SOSIO-HISTORIS)
}

\author{
Rose Fitria Lutfiana, Ahmad Arif Widianto \\ Fakultas Keguruan dan Ilmu Pendidikan Universitas Muhammadiyah Malang \\ Email: rose@umm.ac.id
}

\begin{abstract}
ABSTRAK
Gerakan mahasiswa turut mewarnai perkembangan demokrasi pada lintas orde kekuasaan di Indonesia. Dinamika demokrasi di Indonesia tidak lepas dari beragam aksi gerakan mahasiswa sebagai bentuk aksi moral dan politis untuk memperjuangkan masyarakat dari ketidakadilan dan penindasan. Gerakan mahasiswa merepresentasikan partisipasi politik dalam bentuk konvensional maupun non-konvensional dan sekaligus menyemai praktik demokrasi di Indonesia. Namun dinamika gerakan mahasiswa diwarnai beragam aksi represi berupa kekerasan oleh aparat pemerintah dan oleh mahasiswa sendiri sebagai respon terhadap penindasan. Artikel ini bertujuan untuk menjelaskan secara sosio-historis bentukbentuk gerakan mahasiswa sebagai manifestasi partisipasi politik dan kekerasan-kekerasan yang menyertainya. Artikel ini merupakan refleksi kritis terhadap dinamika perjuangan gerakan mahasiswa dalam kancah demokrasi nasional. Gerakan Mahasiswa dalam hal ini merupakan praksis sosial yang berlandaskan pada nilai-nilai moral untuk mewujudkan kehidupan masyarakat yang ideal. Untuk mewujudkan tujuan itu, Mahasiswa melakukan kajian ilmiah, membentuk lembaga swadaya masyarakat, mobilisasi massa, demonstrasi atau protes, advokasi sosial dan intervensi kebijakan politis pemerintah. Kekerasan terhadap gerakan mahasiswa merupakan konsekuensi perjuangan mereka yang terkadang menentang kekuasaan dan status quo pemerintah. Perubahan sosial yang diperjuangkan mahasiswa butuh perjuangan dan pengorbanan. Kasus kerusuhan, penculikan dan pembunuhan mahasiwa setidaknya menggambarkan parade kekerasan yang dialami oleh gerakan mahasiswa.
\end{abstract}

Kata Kunci: Demokrasi, partisipasi politik, kekerasan, gerakan mahasiswa

\begin{abstract}
The student movement colored the development of democracy across the order of power in Indonesia. The dynamics of democracy in Indonesia cannot be separated from the various actions of the student movement as a form of moral and political action to fight for society from injustice and oppression. The student movement represents political participation in conventional and non-conventional forms and at the same time sowing the practice of democracy in Indonesia. But the dynamics of the student movement are colored by various acts of repression in the form of violence by government officials and by students themselves in response to oppression. This article aims to explainNomor 1, Meisocio-historically the forms of student movements as manifestations of political participation and the accompanying violence. This article is a critical reflection on the dynamics of the struggle of the student movement in the arena of national democracy. The Student Movement in this case is a social praxis based on moral values ??to realize the ideal community life. To realize this goal, students conduct scientific studies, establish non-governmental organizations, mass mobilization, demonstrations or protests, social advocacy and government policy intervention. Violence against the student movement is a consequence of the struggle of those who sometimes oppose the power and status quo
\end{abstract}


of the government. The social change fought for by students needs struggle and sacrifice. Cases of riots, kidnappings and student killings at least illustrate the violent parade experienced by the student movement

Keywords: Democracy;Political Participation;Violence;Students Movement

\section{PENDAHULUAN}

Perkembangan demokrasi di Indonesia kini memasuki era baru. Demokrasi di Indonesia kini menguat dan menjadi gelanggang partisipasi politik yang tidak hanya seremonial, melainkan mengakar di kehidupan masrakat dari berbagai elemen. Keterlibatan masyarakat dalam proses demokrasi tersalurkan melalui banyak ragam jalan dan tanpa tekanan sebagaimana kehidupan demokrasi yang menjadi kenangan buruk silam. Demokrasi menjadi lebih terbuka, partisipasi politik masyarakat semua lapisan berjalan proporsional, menyentuh segala aspek dan kalangan masyarakat. Gerakan mahasiswa salah satunya, telah menjadi indikasi bahwa demokrasi di Indonesia kini adalah milik seluruh warga Indonesia.

Beberapa kajian terdahulu menunjukkan bahwa pergerakan mahasiswa identik dengan partisipasi politik dalam bentuk yang lebih luas untuk mengembangkan kehidupan yang demokratis (Darmayadi, 2011). Meskipun demikian, beberapa kalangan mem-pertanyakan arah perjuangan gerakan mahasiswa apakah berorientasi pada nilai-nilai moral atau cenderung bertujuan untuk kepentingan politis. Gerakan mahasiswa sebagai gerakan moral bertujuan untuk membebaskan masyarakat dari belenggu penindasan dan ketidakadilan pihak penguasa. Di sisi lain, gerakan mahasiswa bernuansa politik ketika lebih mengutamakan kepentingan mobilisasi atau mempertahankan kekuasaan politis. (Usman, 1999).
Gerakan mahasiswa sebagai jalur partisipasi politik mempunyai fungsi vital bagi stabilitas dan perubahan negeri ini. Namun, dalam perkembangannya, gerakan mahasiswa tidak jarang diwarnai kekerasan. Sejarah juga telah menunjukkan perjuangan mahasiswa dalam menyuarakan aspirasi melalui sebuah gerakan seringkali ditempuh dengan pengorbanan baik moril maupun materiil. Persoalan tersebut yang kemudian membesitkan pertanyaan, mengapa gerakan mahasiswa seringkali berakhir dengan kekerasan? Apakah hal tersebut merupakan tradisi atau konstruksi? Artikel ini bertujuan untuk menjawab pertanyaan tersebut dan menguraikan faktor-faktor penyebab kekerasan yang mewarnai gerakan mahasiswa. Lebih khusus lagi terkait dengan kepercayaan masyarakat pada mahasiswa dan pemerintah serta kelanjutan peran dan fungsi mahasiswa sebagai agen perubahan. Tujuannya adalah untuk membongkar akar kekerasan yang kerap terjadi mengiringi gerakan mahasiswa agar tidak menimbulkan salah tafsir terhadap gerakan mahasiswa apalagi menuduh gerakan mahasiswa hanya gerakan radikal belaka.

\section{METODE}

Metode yang digunakan dalam artikel ini adalah refleksi kritis melalui kajian literatur untuk menganalisis fenomena partisipasi politik dan kekerasan dalam gerakan mahasiswa di Indonesia. Untuk menjelaskan kaitan dan pengaruh antara partisipasi politik dan kekerasan dalam gerakan mahasiswa digunakan analisis sosio-historis terhadap data-data terkait

Rose Fitria L, Ahmad Arif W. Meruntuhkan Status Quo: Partisipasi Politik dan Kekerasan dalam Gerakan Mahasiswa di Indonesia (Tinjauan Sosio-Historis) 
bentuk, pola gerakan dan kasus kekerasan dalam gerakan mahasiswa. Beragam kasus kekerasan dalam gerakan mahasiswa digambarkan secara kronologis dan eksplanatif untuk mengurai akar kekerasan. Analisis data dilakukan dengan memadukan kebenaran obyektif dari data dari buku dan media massa.

\section{HASIL dan PEMBAHASAN}

\section{Sejarah dan Konsepsi Partisipasi Politik}

Pada awalnya studi mengenai politik memfokuskan diri pada partai politik sebagai pelaku utama, tetapi dengan berkembangnya demokrasi banyak muncul kelompok masyarakat yang juga ingin mempengaruhi proses pengambilan keputusan mengenai kebijakan umum. Kelompok-kelompok ini lahir pada masa pasca industrial (Post-industrial) dan dinamakan gerakan sosial baru (new social movement). Kelompok-kelompok ini kecewa dengan kinerja partai dan cenderung memusatkan perhatian pada satu masalah tertentu saja dengan harapan akan lebih efektif memengaruhi proses pengambilan keputusan melalui direct action (Budiarjo, 2007:367).

Sebagai definisi umum dapat dikatakan bahwa partisipasi politik adalah kegiatan seseorang atau kelompok orang untuk ikut serta aktif dalam kehidupan politik, antara lain dengan jalan memilih pemimpin negara dan secara langsung atau tidak langsung mempengaruhi kebijakan pemerintah. Kegiatan ini mencakup memberikan suara dalam pemilihan umum, menghadiri rapat umum, mengadakan hubungan atau lobbying dengan pejabat pemerintah atau anggota parlemen, menjadi anggota partai atau salah satu gerakan sosial dengan direct actionnya (Ibid, :367). Samuel P. Huntington dan Joan M. Nelson,
(1977: 3) memberi tafsiran luas terhadap pengertian partisipasi politik dengan memasukkan secara eksplisit tindakan ilegal dan kekerasan. “ By political participation we mean activity by private citizens designed to influence government desicion masking. Participation may be individualor collective, organized or spontaneous, sustained or sporadic, peaceful or violent, legal or illegal, effective or ineffective”. Huntington dan Nelson menganggap bahwa kegiatan yang ada unsur destruktifnya seperti demonstrasi, teror, pembubuhan politik dan lain-lain merupakan suatu bentuk partisipasi politik (Ibid, 1977 :13). Bentuk partisipasi politik yang demikian ini tidak menutup kemungkinan melibatkan dan dipengaruhi oleh pihak di luar partisipan (individu atau kelompok).

Dalam konteks ini, partisipasi politik bukan hanya sekedar menyalurkan aspirasi melalui pemberian suara saat pemilihan umum saja, melainkan keterlibatan masyarakat di luar hal tersebut. Lebih jelasnya, simak pembagian partisipasi politik oleh Gabriel Almond dalam Mochtar Mas'oed dan Mac Andrew (1995:48) yang membedakan partisipasi politik menjadi dua bentuk aksi, yaitu:

1. Partisipasi politik konvensional, yaitu bentuk partisipasi politik yang "normal" dalam demokrasi modern. Seperti; pemberian suara, diskusi politik, kegiatan kampanye, membentuk dan bergabung dengan kelompok kepentingan dan komunikasi individual dengan pejabat politik dan administrasi.

2. Partisipasi politik non-konvensional, yaitu kegiatan ilegal dan bahkan penuh kekerasan dan revolusioner. Seperti: Demonstrasi, pengajuan petisi, tindakan kekerasan politik terhadap manusia (pembunuhan dan penculikan) dan lain sebagainya.

Jurnal Civic Hukum Volume 3, Nomor 1, Mei 2018, hal. 92-101 
Kedua partisipasi politik di atas seringkali berjalan bersamaan. Namun, bentuk aksi yang kedua lebih dominan saat partisipasi politik konvensional telah dilakukan.

Sebuah kegiatan atau gerakan dapat dikatakan merepresentasikan partisipasi politik apabila memenuhi batasan kriteria berikut (Surbakti, 1992: 140-142): (1) perilaku atau kegiatan yang nyata dan dapat diamati, bukan berupa sikap dan orientasi (2) bertujuan untuk mempengaruhi dan intervensi kebijakan pemerintah (3) mengisi kegagalan pemerintah dalam implementasi program dan kebijakan (4) menggunakan kelompok perantara untuk mediasi intervensi dan menekan kebijakan pemerintah (5) sesuai dengan prosedur demokrasi yang berlaku seperti petisi, pemilu, lobby langsung, korespondensi surat-menyurat dan partisipasi politik non konvensional seperti mogok kerja, pembangkanagan dan lain sebagainya.

Dalam prakteknya, Tidak semua bentuk dan tingkat partisipasi politik masyarakat berada pada kesamaan dengan yang lainnya. Masyarakat memiliki tingkat partisipasi politik yang berbeda-beda. Sebagaimana yang dikategorisasikan oleh David F. Roth dan Frank L. Wilson (1976:159) dalam piramida partisipasi politik yang melihat masyarakat dalam empat kategori (seperti yang dikutip oleh Budiarjo, 2007: 373, dan Said Gatara, 1999: 94);

1. Aktivis: The Deviant, termasuk di dalamnya pembunuh dengan maksud politik, pembajak dan teroris, dan Pejabat publik serta fungsionaris partai politik atau kelompok kepentingan)

2. Partisipan: orang yang bekerja untuk kampanye, anggota partai secara aktif, partisipan aktif dalam kelompok kepentingan dan tindakan-tindakan yang bersifat politis dan orang-orang yang terlibat dalam komunitas proyek.

3. Penonton: Orang-orang yang menghadiri reli-reli politik, anggita dalam kelompok kepentingan, orang yang me-lobby, pemilih, orang yang terlibat dalam diskusi politik dan pemerhati dalam pembangunan politik.

4. Apolitis. Perbedaan tingkat partisipasi di atas disebabkan oleh responsi masyarakat yang beragam terhadap keberlangsungan demokrasi dan kondisi yang berkembang di dalam negara. Di Indonesia, saat ini partisipasi politik telah menunjukkan kemajuan. Banyaknya jumlah parpol dan pemilih yang aktif dalam pemilu, meluasnya gerakan masyarakat dan kesadaran politik yang tinggi menjadi indikator gejala tersebut. Hal itu dipengaruhi oleh beberapa rangsangan yang menurut Weiner (dikutip Suryadi, 2007:128) ada lima penyebab (rangsangan) timbulnya gerakan ke arah partisipasi yang lebih luas dalam proses politik. Diantaranya adalah poin kedua dan ketiga yaitu perubahanperubahan struktur kelas sehingga timbul pertanyaan mengenai siapa yang berhak berpartisipasi dan pembuat keputusan, pengaruh kaum intelektual dan komunikasi massa modern.

Almond dan Verba (1984) membagi budaya politik menjadi tiga, yakni budaya politik parokial, budaya politik kaula, dan budaya politik partisipan. Dalam budaya politik parokial tingkat partisipasi politik masyarakat sangat rendah, hal ini dikarenakan rendahnya tingkat pendidikan. Sedangkan dalam budaya politik kaula masyarakat dikaji dari tingkat sosial ekonominya dikategorikan relatif maju namun partisipasi politiknya masih pasif dan budaya politik partisipan partisipasi masyarakat bisa dikatakan sangat tinggi.

Rose Fitria L, Ahmad Arif W. Meruntuhkan Status Quo: Partisipasi Politik dan Kekerasan dalam Gerakan Mahasiswa di Indonesia (Tinjauan Sosio-Historis) 
Perbedaan struktural yang ada dalam budaya politik parokial menyebabkan seseorang tidak mampu mengorientasikan diri mereka pada sistem politik yang secara struktural terdiferensiasi. Orang-orang dengan budaya politik parokial cenderung bersikap apatis terhadap sistem politik. Namun, yang terjadi dalam budaya politik kaula cenderung menjadikan seseorang bersikap aktif terhadap sistem-sistem politik yang secara struktural terdiferensiasi, khususnya terhadap sisi input dari sistem politik, namun bersikap pasif terhadap sisi input sistem politik tersebut. Sejalan dengan budaya politik parokial, budaya politik kaula ditandai dengan ketiadaan orientasi terhadap partisipasi seseorang di dalam sisi input dari suatu proses politik.

Sedangkan dalam budaya politik partisipan ditandai adanya orientasi yang terjadi dalam sistem politik yang terdiferensiasi secara struktural atau terhadap sisi output sistem politik, namun juga terhadap sisi input dari sistem politik dan terhadap diri sebagai partisipan aktif. Tetapi budaya politik partisipan ini tidak serta merta menghilangkan budaya politik parokial dan subjek yang telah dipaparkan di atas. Namun orientasi partisipan merupakan faktor tambahan. Kerena itu para partisipan tidak secara otomatis meninggalkan orientasi parokial atau primordial mereka.

Perpaduan budaya politik partisipan, subjek dan parokial diyakini memiliki pengaruh positif bagi stabilitas demokrasi. Civic culture sebagaimana dikembangkan oleh Almond dan Verba pada hakikatnya bukanlah sekedar budaya politik partisipan, namun kombinasi antara aktivisme dan pasifisme. Kombinasi antara aktivisme dan pasifisme ini menghasilkan perilaku politik yang moderat, bukan radikal. Orientasinya bukanlah kepada perubahan dalam kehidupan masyarakat dan politik yang bersifat revolusioner, melainkan kepada perubahan yang bersifat gradual (Mujani, 2017).

\section{Gerakan Mahasiswa Sebagai Wujud Partisipasi Politik Kaum Mahasiswa}

Mahasiswa mempunyai peranan besar sebagai agent of change, memiliki kesiapan untuk meneruskan estafet kepemimpinan dan dituntut memiliki kemampuan untuk menangani berbagai macam persolan negara serta dituntut untuk selalu kritis dan peka terhadap permasalahan yang ada di sekitarnya. salah satu cara yang digunakan oleh mahasiswa agar bisa menjalankan peranannya adalah dengan melakukan partisipasi politik. Beberapa ahli mengungkapkan bahwa faktor psikologis mempengaruhi partisipasi mahasiswa, misalnya ketidakpuasan atau deprivasi relatif, baik yang bersifat individual maupun kolektif. Sementara ahli lain berpendapat bahwa faktor politik yang mendasari munculnya partisipasi mahasiswa. (Andik Matulessy, 2008)

Mahasiswa menurut Lewis Coser (dalam Budiman, 1980) memiliki cenderung memiliki sikap kritis dan tidak pernah puas menerima kenyataan yang ada serta selalu mempertanyakan kebenaran yang berlaku saati ini untuk mencari kebenran yang lebih unggul dan ideal. Kegiatan dan gerakan mahasiswa tidak hanya berorientasi secara akademis saja. Tetapi juga difokuskan untuk mencapai tujuan-tujuan politis. Mahasiswa membentuk kelompok studi dan lembaga swadaya masyarakat untuk berkontribusi menyelesaikan permasalahan sosial politik masyarakat (Darmayadi, 2011: 67-68). Mahasiswa sebagai masyarakat sipil juga memiliki hak untuk berpartisipasi dalam kehidupan politik. Namun, bentuk dan domain pertisipasi mahasiswa tidak selalu konvensional. 
Partisipasi politik mahasiswa juga memuat bentuk aksi non-konvensional. Salah satunya adalah mahasiswa berhak menyalurkan pendapat dan mengontrol pemerintahan melalui wadah gerakan mahasiswa. Gerakan mahasiswa tersebut merupakan gerakan sosial baru yang menurut Tarrow dalam bukunya Power in Movement (1994) seperti dikutip Miriam (2007:382) menyatakan bahwa Social Movement are collective challenges by people with common purposes and solidarity in sustained interaction with elites, opponents and authorities. Melalui gerakan itu, segala bentuk aspirasi, kritik dan tujuan diteriakkan untuk mempengaruhi dan merubah kebijakan dan tatanan pemerintahan Mahasiswa dengan "bebas" dapat meneriakkan suaranya dengan perlindungan konstitusi. Hak gerakan mahasiswa melakukan kontrol terhadap parlemen tersebut dijamin oleh konstitusi yang dinyatakan dalam pasal 28 UUD Negera Republik Indonesia Tahun 1945 yakni kemerdekaan untuk berkumpul dan menyatakan pendapat.

Mahasiswa sebagai komponen sosial tak lepas dari kaitan-kaitan dialektik dengan struktur yang ada, sosial, ekonomi atau politik. Mereka sebagai pelaku (agen atau aktor sosial) harus melakukan respon terhadap perubahan yang terjadi. Tetapi pada saat yang sama, respon itu juga dilatari oleh kesejarahan dan struktural yang ada. Akibatnya, fungsi dan peran mahasiswa selalu dalam perubahan (Hikam, 1999:222). Mahasiswa ditutut mampu menjalankan peran dan fungisnya. Sudah diketahui bahwa mahasiswa memiliki dua fungsi yaitu fungsi primer dan sekunder. Fungsi Primer mahasiswa adalah mahasiswa adalah orang yang belajar di perguruan tinggi untuk mempersiapkan dirinya bagi suatu keahlian tingkat sarjana. Fungsi
Sekunder, mahasiswa juga aktif dalam persoalan politik. Para mahasiswa mau menjadi kekuatan sosial di antara kekuatan sosial lainnya, seperti partai-partai politik (Arief Budiman, 1999:251).

Peran dan fungsi mahasiswa yang dinilai tinggi di masyarakat menyaratkan mahasiswa untuk memanfaatkan kelebihan yang dimilikinya untuk merespon perubahan. Setidaknya ada tiga respon mahasiswa terhadap perubahan yang berkembang di masyarakat yaitu: 1 . Pragmatik dan mengikuti supply and demand dengan tujuan memenuhi pasar. 2. Berpegang pada idealisme mahasiswa sebagai kekuatan sosial yang harus mewarnai gerak masyarakat terutama dalam politik. 3. Memberikan kritik pada kondisi yang ada dalam lingkungan baik makro ataupun mikro (Hikam, 1999:229). Dengan demikian, gerakan mahasiswa selain sebagai bentuk partisipasi politik juga merupakan perwujudan peran dan fungsi mahasiswa bagi masyarakat. Oleh karena itu, dalam setiap gerakannya mahasiswa mengusung ideologi, kepentingan dan idealisme yang tinggi, yaitu untuk mewujudkan tata pemerintahan yang humanis dan selalu berorientasi pada kepentingan rakyat.

Dalam konteks demokrasi, gerakan mahasiswa menjadi faktor partisipasi politik yang penting dalam masyarakat demokrasi. Kadang-kadang fenomena ini dinamakan demokrasi dari bawah. Mereka bertindak sebagai mediator antara pemerintah dan masyarakat, terutama di akar rumput yang memberikan masukan kepada para pembuat keputusan (Ibid:387). Latar belakang demikianlah yang menyebabkan gerakan mahasiswa mendapat perhatian masyarakat dan pemerintah serta disorot oleh media.

Rose Fitria L, Ahmad Arif W. Meruntuhkan Status Quo: Partisipasi Politik dan Kekerasan dalam Gerakan Mahasiswa di Indonesia (Tinjauan Sosio-Historis) 


\section{Konstruksi Kekerasan dalam Gerakan Mahasiswa}

Sebagai gerakan sosial baru, gerakan mahasiswa tidak selalu mendapat respon baik dari pemerintah. Malahan mendapat tekanan dan perlawanan dari aparat keamanan yang diinstruksi pemerintah. Hal ini terjadi ketika gerakan mahasiswa seperti demonstrasi dan pengajuan petisi yang mengusung kritik. Mereka sangat kritis terhadap cara berpolitik dari para politisi dan pejabat. Cara kerja mereka sebanyak mungkin tanpa tekanan atau paksaan, tetapi melalui lobbying serta networking yang intensif tanpa persuasif. Akan tetapi jika cara ini kurang berhasil, mereka tidak segansegan bertindak lebih keras dengan mengadakan tindakan langsung seperti demonstrasi besar-besaran, pendudukan dan pemogokan yang kadang-kadang berakhir dengan kekerasan (Miriam, 2007: 384).

Dalam sejarah banyak terjadi kekerasan yang menimpa mahasiswa saat melakukan gerakan. Pada tahun 1966 Mahasiswa, memiliki peran strategis dalam mengantarkan proses transisi strategis dari rezim Soekarno ke rezim orde baru di bawah pimpinan Soeharto (Anas, 1998:172). Pada saat itu, militer angkatan darat mendorong mendukung dan memanfaatkan gerakan mahasiswa untuk membubarkan PKI dan menjatuhkan rezim Soekarno. Bagi mahasiswa, militer dipahami sebagai kawan strategis. Sedangkan bagi militer, mahasiswa dipahami sebagai kawan taktis. Turunnya mahasiswa ke jalan raya pada tahun 1966, menurut Arief Budiman (2006:55) merupakan suatu panggilan moral seorang warga negara Indonesia. Pada saat itu, sendi-sendi bernegara secara domokratis telah dalam bahaya. Maka semua bangsa Indonesia terkena kewajiban moral untuk menyelamatkannya.
Konflik antara mahasiswa dan aparat keamanan (pemerintah) yang berujung kekerasan tersebut disebabkan oleh adanya kesenjangan antara tujuan sosial dan caracara mencapai tujuan itu dapat menimbulkan perilaku ekstrem seperti teror dan pembunuhan. Ini sesuai dengan hukum politik: kekerasan adalah jalan dan pilihan terakhir ketika perundingan sudah tidak mungkin. (Emanuel Subangun. 1999:112). Perguruan tinggi yang dikenal otonom dan memiliki kebebasan mimbar, termasuk menjadi obyek garapan yang intensif. Berbagai koridor dipasang tujuannya agar mahasiswa selalu sibuk dengan kegiatan di kampus. Pertemuan ilmiah tidak boleh dilakukan asal tidak membicarakan apalagi melakukan kegiatan politik. Jika ada mahasiswa yang kritis nekat melawan rambu-rambu tersebut akan dihadapi oleh kekuatan bersenjata, oleh tentara (Daliso Mangunkusumo, 1999:55).

Pada beberapa kasus tragedi kekerasan dalam gerakan mahasiswa menunjukkan bahwa kekerasan dalam gerakan mahasiswa merupakan konstruksi dari pemerintah dengan memanfaatkan aparat keamanan. Dalam mengawal gerakan mahasiswa, aparat keamanan cenderung bersikap represif dengan dilakukan penataan artifisual dengan gaya army look style dengan dibentuk Lassus ( Laskar khusus), Passus (Pasukan khusus) dan Satgas (Satuan tugas), dilengkapi dengan sistem organisasi dengan model regu, pleton, kompi dan batalion. Pakaian yang dikenakan pun lengkap army style, sepatu laras, doreng, kopelprem, baret, tanda kesatuan dan embleem pengenal. Secara konstitusional maupun teoritik, TNI menempati posisi amat strategis dalam setting kenegaraan dan perpolitikan nasional, dalam hal ini diberi hak yang sah untuk melakukan political violence (Bambang Cipto. 1999:199). 
Konflik antara pemuda dan mahasiswa dengan pemerintah Soeharto yang pertama kali terjadi pada 1970, dengan gerakan yang dikenal dengan nama mahasiswa menggugat. Pada 15 Mei 1974 terjadi gerakan mahasiswa UI yang menolak investasi asing di Indonesia. Gerakan mahasiswa tersebut terkenal dengan Peristiwa Malari 1974 karena terjadi malapetaka berupa perusakan dan pembakaran oleh massa. Belakangan terungkap peristiwa itu tak lepas dari rekayasa militer yang memang bertujuan untuk membungkam gerakan mahasiswa. Depolitisasi lantas diberlakukan. Pada tahun 1978, dewan mahasiswa diberangus digantikan dengan lembaga senat mahasiswa yang secara sistemik eksistensinya berada di bawah bayangbayang rektorat.

Tahun 1990-an mencatatkan perubahan signifikan bagi pola gerakan mahasiswa maupun konteks radikalisasi gerakan mengejutkan berbagai pihak. Radikal karena memberontak setiap manifestasi politik yang terjadi. Tak dapat dipungkiri kehadiran laskar-laskar baru gerakan era 1990-an memiliki peran signifikan bagi penumbuhan kesadaran kolektif bahwa kebekuan sistem sosial politik harus direformasi. Nyaris di berbagai kota tumbuh kelompok mahasiswa yang kritis dan berani tampil ke depan. Di Jakarta misalnya ada Forkot (Forum Kota), KAMMI (Kesatuan Aksi Mahasiswa Muslim Indonesia, FKSMJ (Forum Komunikasi Senat Mahasiswa Jakarta), KBUI (Keluarga Besar Universitas Indonesia), Front Jakarta, Famred (Forum Aksi Mahasiswa dan Demokrasi), Gempur, Gerakan Mahasiswa Pancasila untuk Demokrasi, Forum Salemba dan lain sebagainya (Tajuk 1-13/ 1/1999).
Bentrokan juga terjadi di Universitas Trisakti (12/5/1998) yang mengakibatkan gugurnya empat orang mahasiswa, masingmasing Elang Mulia (20), Hendriawan Lesmana (20), Heri Hartanto (21) dan Hafidin Royan (22). Tak jelas siapa penembaknya karena aparat keamanan pun mengaku melepaskan peluru karet. Gerakan mahasiswa 1998 sesungguhnya adalah pemberontakan paling dramatis dan otentik dalam sejarah Indonesia karena gerakan mahasiswa mampu meruntuhkan mitologi politik bahwa gerakan mahasiswa adalah aliansi atau bahkan dukungan militer. ABRI tampak gagal mengendalikan berbagai kerusuhan yang meletup di Jakarta, .Solo dan berbagai kota lainnya pasca penembakan mahasiswa Universitas Trisakti, 12 Mei 1998. Kerusuhan terbesar diikuti penjarahan dan pembakaranpembakaran terjadi pada 13-14 Mei 1998. Peristiwa serupa juga terlihat pada bentrokan antara aparat keamanan dan mahasiswa yang melakukan aksi di Institut Agama Islam Negeri (IAIN) Syarif Hidayatulloh Jakarta yang mengakibatkan tiga petugas keamanan luka-luka.

\section{Simpulan dan Rekomendasi: Perlunya Kesadaran Bersama dalam Mengawal Gerakan Mahasiswa}

Pertanyaan yang mengawali tulisan ini sudah terjawab dengan penjelasan dan bukti yang disajikan di atas. Kekerasan yang selama ini mewarnai gerakan mahasiswa sebagai wujud partisipasi politiknya terjadi akibat respon pemerintah yang terlalu berlebihan terhadap kritik mahasiswa. Aparat pemerintah merupakan pihak yang langsung berhadapan dengan gelombang gerakan mahasiswa. Mereka menampilkan sisi garang mereka ketika mengawal arus demonstrasi mahasiswa. Dan tak jarang pecah bentrok yang menjurus ke konflik dan kekerasan di antara

Rose Fitria L, Ahmad Arif W. Meruntuhkan Status Quo: Partisipasi Politik dan Kekerasan dalam Gerakan Mahasiswa di Indonesia (Tinjauan Sosio-Historis) 
keduanya. Namun, dibalik itu semua, rupanya peristiwa itu merupakan instruksi dari atasan (pemerintah) belaka yang wajib dilaksanakan oleh aparat keamanan. Hal ini terbukti pada kasus kekerasan pada peristiwa Malaria 1974 yang merupakan rekayasa pemerintah untuk meredam demonstrasi mahasiswa.

Sudah seharusnya mahasiswa dan aparat keamanan menyadari bahwa demonstrasi merupakan bentuk praktek demokrasi yang nyata. Partisipasi politik mahasiswa tersebut hendaknya dimanfaatkan oleh mahasiswa dan didukung oleh aparat keamanan untuk memperjuangkan kepentingan rakyat. Hubungan baik antara gerakan mahasiswa dan aparat keamanan yang pernah proaktif seperti pada saat pembubaran PKI dan penurunan rezim Soekarno harus kembali dibangun agar demokrasi dan stabilitas pemerintahan nasional dapat berlangsung tertib.

Untuk mewujudkan demokrasi tanpa kekerasan diperlukan kecerdasan intelektual dan kemapanan emosional (Daliso, 1999:111). Mantan Menhankam/ Pangab, Jenderal TNI Wiranto juga pernah mengingatkan kalau mahasiswa tetap mempertahankan demonstrasi, yang dampaknya menimbulkan kerusuhan, berarti akan menambah dan memberatkan situasi dan beban masyarakat. (8 Mei 1998 hal. 74). Pemerintah melalui aparat keamananannya juga harus terbuka terhadap gerakan mahasiswa sebagai bentuk dukungan mereka terhadap kehidupan berdemokrasi. Dan akhirnya, jika pemerintah ingin kehidupan domokrasi di Indonesia dapat berlangsung dengan aman dan tertib, maka kepedulian dan sikap legawa harus ditonjolkan dari pada menutup diri bahkan represif. Demikian juga Mahasiswa sebagai kaum intelektual harus sadar akan peran dan fungsinya di masyarakat. Sudah semestinya mereka berpartisipasi dengan cerdas dan tanpa dipenuhi emosi agar proses demokrasi terjaga dan tidak cidera oleh kekerasankekerasan di dalamnya.

\section{DAFTAR PUSTAKA}

Almond, Gabriel A. dan Sidney Verba. 1984. Budaya Politik : Tingkah Laku Politik dan Demokrasi di Lima Negara. Terjemahan Shat Simamora.Jakarta: Bina Aksara, Co.

Andik Matulessy, Disertasi. 2008. Model Kausal Partisipasi Politik Aktivis Gerakan Mahasiswa. Universitas Gadjah Mada.

Budiarja, Miriam. 2008. Dasar-dasar Ilmu Politik. PT. Gramedia Pustaka Utama.

Budiman, Arief. 2006. Kebebasan, Negara, Pembangunan: Kumpulan Tulisan 1965-2005. Jakarta: Freedom Institute.

Budiman, Arif. 1980. Peranan Mahasiswa sebagai intelegensia. Dalam Dick Hartoko, Golongan Cendekiawan: Mereka yang berumah di atas Angin. Jakarta: PT. Gramedia.

Cipto, Bambang. 1999. Masa Depan Peranan Militer. Dalam Jurnal Wacana. No. 11. 1999.

Darmayadi, Andrias. 2011. Pergerakan Mahasiswa dalam Perspektif Partisipasi Politik: Partisipasi Otonom atau Mobilisasi. Majalah Ilmiah Unikom Vol.9, No. 1

Hikam, Muhammad A.S.. 1999. Politik Kewarganegaraan: Landasan Redemokratisasi Indonesia. Jakarta: Erlangga.

Huntington, Samuel P. dan Joan M. Nelson. 1977. No Easy Choice: Political Participation ini Developing Countries. Cambridge, Mass: Harvard University Press. 
Mangunkusumo, Daliso. 1999. Tradisi Kekerasan Politik di Indonesia. Yogyakarta: L.K. Prospek.

Mujani, Saiful. 2007. Muslim Demokrat: Islam, Budaya Demokrasi, dan Partisipasi Politik di Indonesia Pasca Orde Baru. Jakarta: Gramdia Pustaka Utama.

Roth, David F. dan Frank L. Wilson. 1976. The Comparative Study of Politics. ed. Ke-2. Boston: Houghton Mifflin Company.

Subangun, Emanuel. 1999. Politik Anti Kekerasan Paska Pemilu 1999. Yogyakarta: Pustaka Pelajar.

Surbakti, Ramlan. 1992. Memahami Ilmu Politik. Jakarta: PT. Gramedia.

Suryadi, Budi. 2007. Sosiologi Politik: Sejarah, Definisi, dan perkembangan konsep. Yogyakarta: IRCiSoD.

Urbaningrum, Anas.1998. Ranjau-ranjau Reformasi: Potret Konflik Politik Pasca Kejatuhan Soeharto. Jakarta: PT. Grafindo Persada.

Usman, Sunyoto. 1999. Arah Gerakan Mahasiswa: Gerakan Politik ataukah Gerakan Moral?. Jurnal Ilmu Sosial \& Politik. Vol. 3. No. 2 1999.

Rose Fitria L, Ahmad Arif W. Meruntuhkan Status Quo: Partisipasi Politik dan Kekerasan dalam Gerakan Mahasiswa di Indonesia (Tinjauan Sosio-Historis) 